\title{
TRANSFORMATION OF THE TAXATION SYSTEM AND ITS INFLUENCE ON ENTERPRISE DEVELOPMENT IN THE REPUBLIC OF UZBEKISTAN
}

\author{
FURKAT BAZAROV
}

Tashkent Institute of Finance, Uzbekistan

\section{ABSTRACT}

The research studies impacts of new tax changes to the small businesses, unemployment and to economic growth in Uzbekistan. The study shows that the tax policy directed on perfection of tax mechanisms, reduction of tax rates aimed to raise economic efficiency of manufacturing and increasing individual income. As a result from year to year the tax burden is reduced and the taxation order becomes simpler. Empirical analysis shows that only for last seven years the general tax burden in economy was reduced with 40 to 27 percent. The author found problems existing in small business taxation and generalizes recommendations for simplification of tax system and tax administration.

\section{JEL CLASSIFICATION \& KEYWORDS}

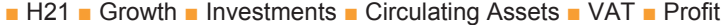
Tax $\approx$ Unified Tax Payment $\approx$ Off-budget Pension Fund $\approx$ Road Fund

\section{INTRODUCTION}

\section{ECONOMIC REFORMS AND TAX POLICY}

Transformation of economic system in Uzbekistan has claimed changes and formation of new economic entities adequate to market requirements and competitive environment. Priority directions of economic reforms implemented in Uzbekistan are defined as development of private enterprises, creation of middle class of proprietors and change in legislation.

The decree of President of the Republic of Uzbekistan from 2009 \#PD-1112 «About measures on the further support and development of enterprise activity» aims for further development of a small business and private enterprise and increasing of their role in steady functioning of a national economy. The main purpose of these measures promoted increasing the contribution of the small business in economic growth, creation of new workplaces, increasing employment and maintenance the qualitative changes in economy. The analysis shows that small business growth rate in 2008 was Figure 1. Dynamics of the contribution of (\%)

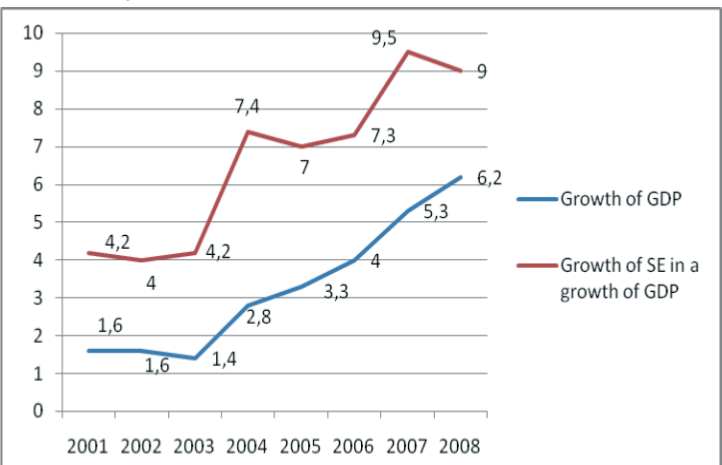

Source: The State committee of Republic Uzbekistan on statistics.

$6,2 \%$ or has increased on 0,9 points in relation to 2007 (Figure. 1.) In 2008 small business and private enterprise there were employed 8024,1 thousand people or $72,7 \%$ of all number employed in economy, these figures more almost $20 \%$ in comparison with 2001 .

The tax policy is defined as main instrument of stimulation of small businesses which is currently aims perfection of tax mechanisms, reduction of tax rates to raise manufacturing, to increase population incomes. As a result from year to year the tax burden is reduced and the taxation order becomes simpler. Only for last seven years the general tax burden in economy was reduced with 40 to 27 percent. As result, financial resources of the enterprises have been essentially increased, which became an additional source for growth of investments, replenishment of assets, increase of working capital and wages.

The decision by the President from 2009 «About additional measures on expansion of production of foodstuffs and home market saturation» defined, that since July $1^{\text {st }}$ of 2009 , microfirms and the small enterprises operating in sphere of processing and manufacture of meat-and-milk outputs on an industrial basis, pay Unified tax payment under the rate reduced for 50 percent.

Based on the Decision of the President from 2009 «About additional measures to increase stimulation of manufacturing and quality improvement of wall materials» for the period from July 1st, till January 1st of 2012 the enterprises making burned brick on the basis of modern technologies with use of special furnaces (ring, tunnel, etc.), are released from payment of all types of tax, obligatory deductions to all state funds.

\section{THE NEW TAX CODE}

With a view of the further perfection of a tax policy as priority direction of extending economic reforms under the initiative of the President was introduced the new The Tax Code since January $1^{\text {st }}$ of 2008 . There has been developed transformation of operating tax system in its basis. The importance is to reform tax administration and development of principles of the taxation according to the international standards. The innovations reflected in the new Tax Code:

- The Code became the document of direct actions, i.e. it regulates the questions connected with the taxation, without references to other standard documents;

- Established precise term between acceptance of certificates of tax laws and their introduction in action that creates guarantees of maintenance of stability of tax laws for tax bearers (Article 3 of the Tax Code of the Republic of Uzbekistan).

- Introduced the interdiction for granting of individual privileges under taxes;

- It is established, that performance by the tax bearer of written explanations from the authorized bodies releases him from violation of the tax laws liability; 
Printed from: Serif PagePlus 14,0,5,27 Copyright (๑) 1994-2009 Serif (Europe) Ltd. All Rights Reserved

Printed on: 28.3.2011 18:39:46

Publication name: Journals.cz_EJBE_Vol2.ppp, Page: 2

- Expanded the action of some privileges regarding VAT;

- The zero rate of the VAT is extended to all export (earlier zero rate extended only for export for hard currency);

- Privileges under the VAT and the profit tax are extended to rent of any property, irrespective of the acquisition purposes:

- The ecological tax is cancelled; collection for the trade right; collection for the right of trade in tobacco;

- Unified tax was introduced for trade and catering businesses;

- Introduced Collection for the trade right are by precious metals; for rendering of paid services in motor transport parking;

- The rate of Unified tax payment is reduced from $13 \%$ in 2005 to $8 \%$ in 2008 ;

- The rate of the tax to incomes (profit) of legal bodies is reduced from $15 \%$ in 2005 to $10 \%$ in 2007.

\section{THE ANALYSIS OF UNIFIED TAX PAYMENT AFFECTS}

In 2005 Unified tax payment has introduced for majority of subjects of small and private business in Uzbekistan. It has considerably reduced not only tax burden, but also simplified accounting and the reporting. In 2009 small enterprises and microfirms have the preferential conditions for Unified tax payment. For example manufacturers of computer software products will pay $80 \%$ comparing to other companies from their total sales. So in other words it's $5 \%$. Agriculture firms taxed at the rate of $6 \%$ / where the other small enterprises and microfirms taxed at the rate of $8 \%$.

Decrease in the rate of Unified tax payment and the profit tax leads to constant decrease in tax burden on the enterprises. So, in 2006 tax deductions (the sum of all taxes paid within year and obligatory payments) small business enterprises was on the average $18 \%$ and it reduced to $15 \%$ in 2008 (Fig.2.)

Figure 2. The sum of the paid taxes in relation to capital gain, $\%$

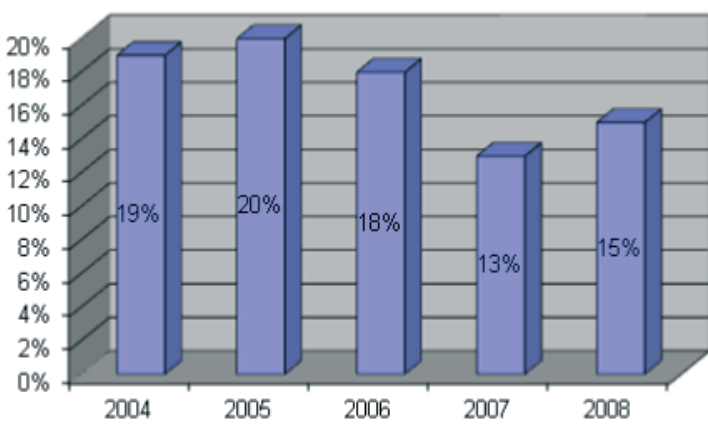

Source: Calculated by the author according to data obtained from the Ministry of Finance of the Republic of Uzbekistan.

When we talk about tax burden, it is necessary to take into consideration all payments, which subjects of business are obliged to make. On the average, the enterprises of the industry, building, trade and catering at the simplified system of the taxation should pay more than five taxes (Fig. 3.).

Rates of separate taxes for example, Unified tax payment (8 \% from a proceeds in 2008) or the profit tax (10\% from profit in 2008) are rather low. Nevertheless, it is necessary to take into consideration, that the number of taxes and the obligatory payments paid by the enterprises (including at the simplified system of the taxation) is high. Besides, the share of Unified tax payment in total incomes of the state
Figure 3. Structure of tax deductions of the enterprises-payers of Unified tax payment

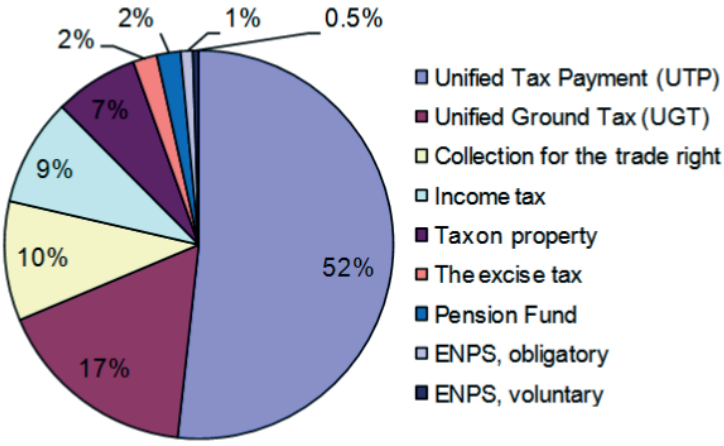

Source: Presented by the author according to data obtained from the Ministry of Finance of the Republic of Uzbekistan.

budget also is insignificant and makes about $9 \%$ of total incomes (Tab. 1.).

The highest tax burden for the small business is obligatory deductions for social payments and deductions to state funds.

Since 2008 the rate of obligatory deductions of the enterprises in the Pension fund also is raised from $0,7 \%$ to $1 \%$. None it can lead to that employer will be interested in

Table 1. Structure of direct taxes (to total volume, \%)

\begin{tabular}{|l|l|l|l|l|l|}
\hline Types of tax & 2004 & 2005 & 2006 & 2007 & 2008 \\
\hline direct taxes & 100 & 100 & 100 & 100 & 100 \\
\hline profit tax of the enterprises & 32 & 28.2 & 28.5 & 28.4 & 28.3 \\
\hline tax to the gross revenue & 0 & 8 & 7.3 & 7.3 & 6.1 \\
\hline unified tax payment & 13.2 & 9.6 & 9.4 & 9.1 & 9.1 \\
\hline $\begin{array}{l}\text { tax to incomes of } \\
\text { individuals }\end{array}$ & 43.8 & 43.4 & 44 & 43.9 & 42.9 \\
\hline fixed taxes & 4.8 & 4.8 & 4.6 & 3.7 & 3.4 \\
\hline $\begin{array}{l}\text { tax to development of a } \\
\text { social infrastructure }\end{array}$ & 6.2 & 6 & 6.2 & 7.6 & 10.2 \\
\hline
\end{tabular}

Source: The Almanac of Uzbekistan 2008. - T: CER, 2009.

official material encouragement of the employees. Some of employers will prefer to solve a problem by informal payments, i.e. breaking the law. In addition, the Pension fund will receive less revenue.

\section{CONCLUSION}

The main tax burden for small businesses in Uzbekistan is consisted from Unified tax payment, and obligatory deductions to state funds (Pension fund, Road funds and Fund of development of school education).

Administration of taxes continues remaining complex enough. One example, that the share of taxes and tax collections calculated from the same taxable base, and they administered separately. The businesses should list the sums of the taxes added from one base into different accounts of corresponding bodies, and on each of taxes to give separate calculations. It increases the administrative burden of the enterprise. So it makes obvious of necessity of further reforms in tax system.

In table 2, the short list of existing problems and causes of those problems, and some recommendations of their solution are presented.

Thus, in transforming processes it is necessary to develop and take the additional measures directed on decrease of 
Printed from: Serif PagePlus 14,0,5,27 Copyright (@ 1994-2009 Serif (Europe) Ltd. All Rights Reserved

Printed on: 28.3.2011 18:39:46

Publication name: Journals.cz_EJBE_Vol2.ppp, Page: 3

VOLUME 2, 2011

tax burden, on simplification of tax legislation and tax administration. Such measures should include:

\begin{tabular}{|c|c|c|c|}
\hline Problems & $\begin{array}{l}\text { The reasons } \\
\text { of problems }\end{array}$ & $\begin{array}{l}\text { Recommendat } \\
\text { ions about the } \\
\text { decision of } \\
\text { problems }\end{array}$ & $\begin{array}{l}\text { Expected } \\
\text { effect }\end{array}$ \\
\hline \multirow[t]{2}{*}{$\begin{array}{l}\text { High tax } \\
\text { deductions }\end{array}$} & $\begin{array}{l}\text { High social } \\
\text { payments and } \\
\text { deductions to } \\
\text { state funds }\end{array}$ & $\begin{array}{l}\text { Reduction of } \\
\text { number of } \\
\text { taxes and } \\
\text { obligatory } \\
\text { payments }\end{array}$ & $\begin{array}{l}\text { Decrease in } \\
\text { tax burden }\end{array}$ \\
\hline & $\begin{array}{l}\text { Practice of } \\
\text { collection of } \\
\text { taxes from } \\
\text { Sales } \\
\end{array}$ & $\begin{array}{l}\text { Improvement } \\
\text { of advisory } \\
\text { support of tax } \\
\text { bearers }\end{array}$ & $\begin{array}{l}\text { Increase in } \\
\text { collecting } \\
\text { taxes }\end{array}$ \\
\hline \multirow[t]{4}{*}{$\begin{array}{l}\text { Difficult tax } \\
\text { administration }\end{array}$} & $\begin{array}{l}\text { Presence of } \\
\text { contradictions } \\
\text { in tax laws }\end{array}$ & $\begin{array}{l}\text { Further } \\
\text { perfection of } \\
\text { the tax laws }\end{array}$ & $\begin{array}{l}\text { Reduction of } \\
\text { illegal } \\
\text { business }\end{array}$ \\
\hline & \multirow[t]{3}{*}{$\begin{array}{l}\text { Still existence } \\
\text { of } \\
\text { considerable } \\
\text { quantity of } \\
\text { taxes and } \\
\text { obligatory } \\
\text { payments }\end{array}$} & $\begin{array}{l}\text { Expansion of } \\
\text { practice of } \\
\text { use of the } \\
\text { electronic } \\
\text { form of the } \\
\text { reporting }\end{array}$ & \multirow[t]{3}{*}{$\begin{array}{l}\text { Reduction of } \\
\text { transaction } \\
\text { costs } \\
\text { connected } \\
\text { with tax } \\
\text { administration }\end{array}$} \\
\hline & & $\begin{array}{l}\text { Working out of } \\
\text { comments to } \\
\text { the Tax Code }\end{array}$ & \\
\hline & & $\begin{array}{l}\text { Increase of } \\
\text { level of legal } \\
\text { literacy of } \\
\text { businessmen }\end{array}$ & \\
\hline
\end{tabular}

Source: Author

First, reduction of number of taxes and obligatory payments.

Reduction of number of raised taxes can become one of measures on decrease in tax burden. For this purpose, it is expedient to unite taxes, which are charged from one base, but are administered separately. For example, it is possible to consider possibility of unification of obligatory deductions in state funds (the Pension fund, Fund of school education and Road fund; and Unified social payment and citizens insurance payments.

Similar reform was held on association of the taxes (collecting) having the general assessed base in the Russian Federation. In 2001 the Unified social tax (UST) which has united in collecting of to the Pension fund of Russia, Fund of obligatory medical insurance, Fund of employment and social insurance. Because of introduction of the Unified tax instead of the several payments collected from the same base, administrative expenses both tax bodies, and tax bearers are cut down.

Experience of unification of the tax payments collecting from the same base, practiced in Uzbekistan as well. In April 2004 deductions to social payments has been unified to the Pension fund, the State fund of assistance of employment and the Federation Council of trade unions are unified. The Unified tax payment entered in July, 2005 has replaced with the Unified tax and obligatory deductions in an off-budget Pension fund, Republican road fund and School education fund.

Second, improvement of advisory support. The priority should be given to the efforts directed for work with tax bearers to help them to understand of tax obligations. Foreign experience testifies, that tax bodies work most effectively in those countries where they play a role not regulatory body, but advisory, focused on consultancy. In
Uzbekistan it is necessary to emphasis in an estimation of an overall performance of tax bodies. More attention should be given not to number of tax law breaking and penalty sanctions, but to decrease in quantity of errors at registration of the tax reporting, to observance of terms of payment of taxes, increase of level of a collecting of taxes and efficiency of consulting work with tax bearers.

Creation of special advisory divisions in tax bodies can become one of priorities. These divisions should have the purpose - rendering of assistance to tax bearers in understanding and application of norms of tax laws. In order to avoid the conflict of employees' interests of tax bodies should carry out the given functions, whose duties do not include realization of tax checks of subjects of business. Creation of advisory divisions of tax bodies becomes more actual as the requirement for tax explanations in connection with acceptance of the new Code.

Simplification of taxation and it's administration, tax advisory support, in our opinion, will yield the following positive results:

- Expenses on tax administration both from the state, and from companies will decrease;

- Gives opportunity to plan more adequately according to business development;

- Makes possible to clearly understand and operatively react to the actions of the state which are carried out through changes of tax laws;

- Will help to reduce illegal operations of businesses.

\section{REFERENCES}

1. The State committee of Republic Uzbekistan on statistics

2. The Almanac of Uzbekistan 2008. - T: CER, 2009 